\title{
Characterizing Unggaran Geothermal Resource Potential in Central Java : Application of Gedongsongo Manifestations Evaluation
}

\author{
Adrian Rizki Sinuhaji ${ }^{\mathrm{a}}$, Yudha Herlambang ${ }^{\mathrm{a}}$ \\ ${ }^{\mathrm{a}}$ Geological Engineering Padjadjaran University,Jalan Raya Bandung - Sumedang, Bandung, 45363, Indonesia
}

\begin{abstract}
Geothermal power is extracted from heat stored in the earth. This paper discusses the use of geothermal energy in our electrical power systems and potential development in Central Java. Gedongsongo surface manifestations of the Ungaran geothermal prospect in Central Java have high temperature properties, (72 to 87) ${ }^{\circ} \mathrm{C}, \mathrm{pH} 2$ to $\mathrm{pH} 6$ and $770 \mathrm{~g} / \mathrm{kg}$ of chloride. Geothermal power plant is very compatible built in Gedongsongo. At present, the development of geothermal resources as renewable energy have to be primarily focused on utilization of ground source heat pumps which can make good use of the enormous low temperature geothermal resources.
\end{abstract}

Keywords: Central Java; Geothermal; renewable energy.

\section{Introduction}

Indonesia have many potential areas to develop geothermal power plant in order to reduce dependence fossil fuels. The Indonesia government has set up a long term energy plan aiming at energy diversification to reduce the country's dependence in oil. One of the renewable energy resources is geothermal energy. Geothermal power is extracted from heat stored in the earth. This geothermal energy originates from the original formation of the planet, from radioactive decay of minerals, and from solar energy absorbed at the surface.

Almost everywhere, the shallow ground or upper $3 \mathrm{~m}$ of the Earth's surface maintains a nearly constant temperature between $10^{\circ} \mathrm{C}$ and $20^{\circ} \mathrm{C}$. Geothermal heat pumps can tap into this resource to heat and cool buildings. A geothermal heat pump system consists of a heat pump, an air delivery system (duct work), and a heat exchanger-a system of pipes buried in the shallow ground near the building. In the winter, the heat pump removes heat from the heat exchanger and pumps it into the indoor air delivery system.

In the summer, the process is reversed, and the heat pump moves heat from the indoor air into the heat exchanger. The heat removed from the indoor air during the summer can also be used to provide a free source of hot water. Potential geothermal energy Indonesia is located in Central Java. There are many volcanoes that have prospect in geothermal energy. Ungaran Volcano is located at northern part of the Java volcanic arc (Figure 1). Java itself is developed by the north-south modern subduction system of the Indian oceanic plate and Eurasian continental plate (Hamilton,1979). Ungaran lies within 4 stratovolcanos range, i.e. Merapi, Merbabu, Telomoyo and Ungaran (from south - north; Bemmelen (1949) describes the Ungaran volcano as composed of augite-olivine basalt-andesite (Lower Pleistocene), augite-olivine basalts (upper Pleistocene), augite-hornblende(biotite) andesite (upper Pleistocene and Holocene) and hornblende andesite (Holocene).

These three distinct compositions are recognized as the products three of major volcanic eruptions which were separated by two collapses structures (Bemmelen, 1949). This structure type might control surface manifestations at Ungaran. Some geothermal manifestations appear to surround Ungaran volcano, i.e. Kali Ulo, Diwak, Banaran and 
Gedongsongo. In this paper, the author focuses on major manifestations that occur at Gedongsongo which is situated at the southern flank of Ungaran summit. An update of manifestation descriptions and fluid origins are described.

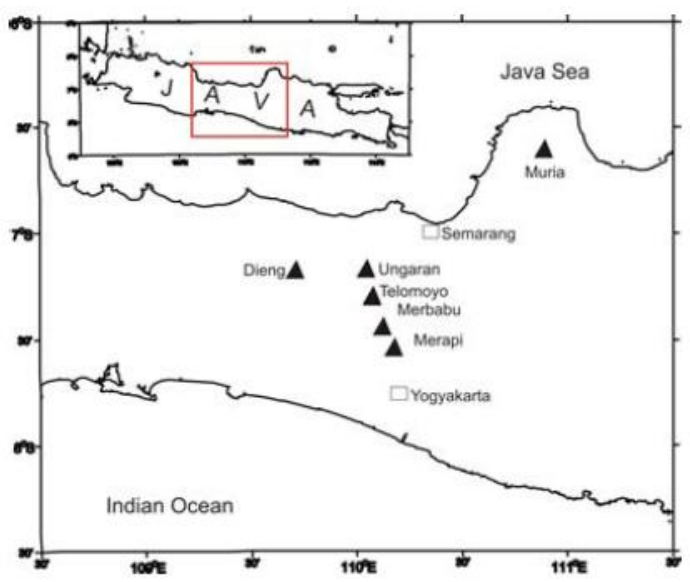

Fig. 1. Location geothermal prospect in Central Java.

\section{Material and method}

\subsection{Geothermal power plant}

The geothermal potential of high-temperature resources suitable for electricity generation with conventional technologies (steam turbines, binary turbines) is spread rather irregularly and depends on the volcanic zones. Geothermal power plants are in operation in 24 countries.

This number is expected to increase to 35 by 2015. The main producers of geothermal energy are the United States (3.1 GW), the Philippines (1.9 GW), Indonesia (1.2 GW) and Mexico (1 GW) (Bertani, 2010). Employment trends point of view, geothermal power plants can be operated by a relatively small number of full time human resources but require continued involvement by geothermal professionals and technicians to maintain the supply of fluid to the surface plant.

Many of these people may not be employed fulltime on one project, but may have input into a number of projects as consultants. March 12th, 2010, the range in capacities for geothermal power as a renewable energy resource is drastic.

Studies of the renewable resource potential indicate an enormous capacity of wind, solar, geothermal, tidal, biomass and hydropower.

Several renewable technologies have matured in the past decade, and growth rates of solar and wind is now at $17 \%$ and $24 \%$ respectively. The leading companies in these two areas today are Shell, BP, Zevron and Siemens-indicating recognition by the energy providers of a growing market opportunity. 
Table 1. Development geothermal power.

\begin{tabular}{|l|l|c|}
\hline Sr. No. & \multicolumn{1}{|c|}{ Country } & Power \\
\hline 1 & United States & $3153.0 \mathrm{MW}$ \\
\hline 2 & Philippines & $2195.3 \mathrm{MW}$ \\
\hline 3 & Indonesia & $1132.0 \mathrm{MW}$ \\
\hline 4 & Mexico & $965.0 \mathrm{MW}$ \\
\hline 5 & Italy & $810.0 \mathrm{MW}$ \\
\hline 6 & New Zealand & $577.0 \mathrm{MW}$ \\
\hline 7 & Japan & $535.0 \mathrm{MW}$ \\
\hline 8 & Kenya & $169.0 \mathrm{MW}$ \\
\hline 9 & Turkey & $83.0 \mathrm{MW}$ \\
\hline 10 & Russian Federation & $81.0 \mathrm{MW}$ \\
\hline
\end{tabular}

\subsection{Geothermal energy and electricity}

The centre of the Earth is around 6000 degrees Celsius - easily hot enough to melt rock. Even a few kilometres down, the temperature can be over 250 degrees Celsius if the Earth's crust is thin. In general, the temperature rises one degree Celsius for every 30 - 50 meter you go down, but this does vary depending on location in volcanic areas, molten rock can be very close to the surface.

Sometimes we can use that heat. Geothermal energy has been used for thousands of years in some countries for cooking and heating. Geothermal energy, that is the long term availability and the large extent of heat contained in the Earth's interior, usually considered as clean and renewable sources on the timescales of technological system is most extensively used worldwide as an effective source for a sustainable supply of energy, because the recovery of high-enthalpy reservoirs would fully recover to its pre-exploitation state after an extended shutdown period or even at the same site from which the fluid or heat is extracted in almost all geothermal projects worldwide.

Moreover, the environmental impacts of geothermal power generation and direct use are generally minor, controllable, or negligible. Geothermal resources include dry steam, hot water, hot dry rock, magma, and ambient ground heat. Steam and water resources have been developed commercially for power generation and ambient ground heat is used commercially in geothermal heat pumps; methods of tapping the other resources are being studied.

Geothermal power projects convert the energy contained in hot rock into electricity by using water to absorb heat from the rock and transport it to the earth's surface, where it is converted to electrical energy through turbinegenerators. Water from high-temperature $\left(>240{ }^{\circ} \mathrm{C}\right)$ reservoirs is partially flashed to steam, and heat is converted to mechanical energy by passing steam through low-pressure steam turbines.

A small fraction of geothermal generation worldwide is generated using a heat exchanger and secondary working fluid to drive the turbine. The geothermal process diagram shows the production wells, separator, scrubber, turbine, condenser, and cooling tower. After being separated from steam, brine is injected back into the reservoir. Steam is piped to the plant where it passes through a scrubber before entering the turbine, and it is then condensed.

Condensed steam is used in the cooling towers, where roughly $80 \%$ evaporates and the remainder is injected back into the reservoir. Exploitable geothermal reservoirs exist in high- temperature, highly permeable, fluid-filled rock within the earth's upper crust, typically in areas associated with young volcanic rocks.

Driven by heat loss from underlying magma, hot fluids rise along pre-existing zones of high permeability. The buoyant up-flowing fluids enhance the permeability of the rocks through which they are flowing by chemical leaching and by explosive boiling. 


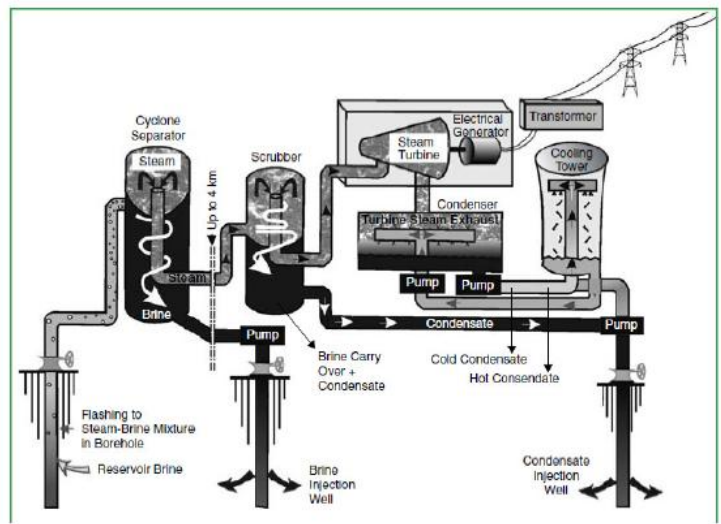

Fig. 2. Geothermal process.

If the system becomes large enough and has high enough permeability, it has the potential to be a commercial grade geothermal reservoir with temperatures typically in the range of (240 to 320$)^{\circ} \mathrm{C}$. The current drilling technology can exploit geothermal reservoirs economically in the depth range of $500 \mathrm{~m}$ to $3000 \mathrm{~m}$.

\subsection{Thermal manifestations}

Thermal manifestations of Gedongsongo are in the form of fumaroles, hot springs and steaming ground. The active thermal manifestations mostly occur in the western part of a small creek on the southern flank of Ungaran summit. Measured temperatures made using a thermistor at the vent of fumaroles (size $0.75 \mathrm{~m} \times 0.50 \mathrm{~m}$ ) reaches $85^{\circ} \mathrm{C}$ (measured in November 2008) with significant mass flow rate (Nukman, in prep.)

The fumarole discharges from steep cliff; whereas steaming ground $(45 \mathrm{~m} \mathrm{x} 30 \mathrm{~m})$ with similar temperatures coexists in higher topography. This suggests that fumaroles were formed due to heated ground water which in bisected topography. The temperature of hot spring (eastern part) and steaming ground (southern part) reaches about $40{ }^{\circ} \mathrm{C}$ and $50{ }^{\circ} \mathrm{C}$, consecutively.

In the eastern part of the creek exist relic manifestations. There are many dead trees covered by sulphur and mud. The sulphur odor can be recognized at very close distance, and there are tiny fractures over the ground also covered by sulphuric mud interpreted as relic warm or hot spring channel mouth.

The altered ignimbrite and andesitic rocks reveals a high alteration intensity ( 0.8 of 1 AI of Browne,1999) and pervasive silica replacement is also present; there are not many feldspar left. Relic epidote also appears at some outcrops.

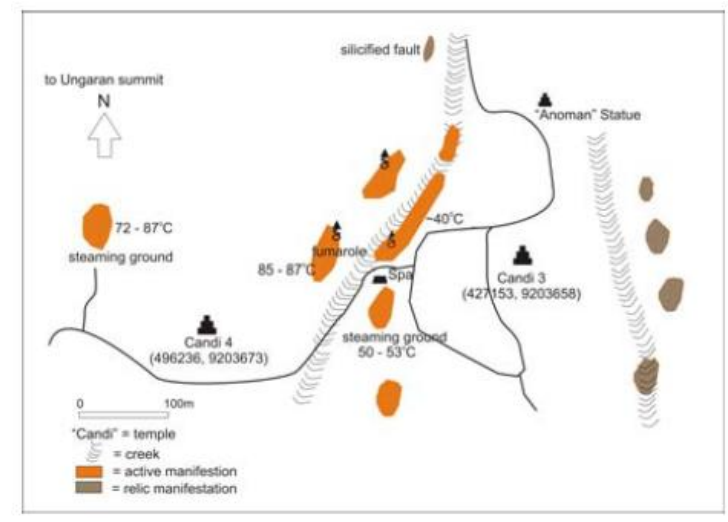

Fig 3. Locality of surface manifestation of Gedongsongo. 


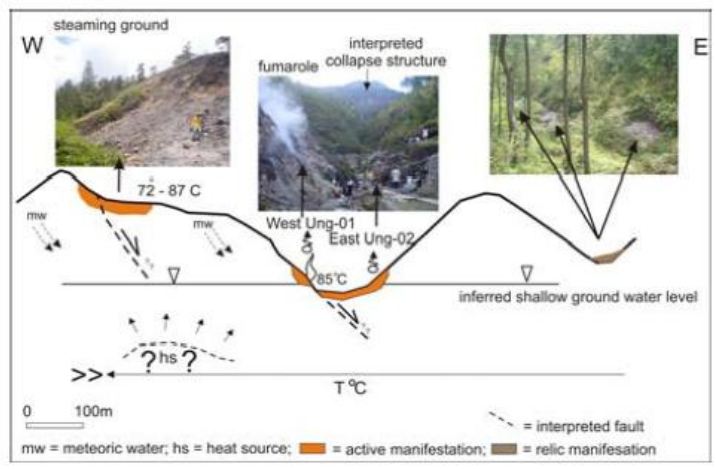

Fig. 4. East-west cross-section over Gedongsongo manifestations (detailed explanation described in the text).

The distribution of manifestations shows a N-S alignment, parallel with steep cliff (and small creek) which possibly formed due to a collapse structure or normal faulting as commonly occur in volcanic regions. This permeable structure is considered to control the convective heat transfer. A silicificied fracture indicating a normal fault is found at the relic steaming ground at northern part. There is no relic epidote in this site.

\subsection{Fluid type and origin}

Water samples of manifestation were collected, filled in rinsed polyethene bottles, fully filled and sealed to avoid any precipitation prior analysis processes. The chemical constituents were analyzed by the Chemistry Department of UGM (Indonesia) and isotopic constituents were measured by GNS Lower Hutt (New Zealand). The chemical composition is shown in Table 2. The West Ung-01 sample was collected from fumaroles at the western cliff; the East Ung-01 was collected from hot spring located just a few meters to east of the West Ung-01 location. The chemical contents are plotted on ternary diagram of $\mathrm{Cl}-\mathrm{SO} 4-\mathrm{HCO} 3$, to identify fluid type, i.e. mature, volcanic, steam heated and peripheral type (Giggenbach,1991). The isotopic composition of water data is plotted in $\delta \mathrm{D}$ versus $\delta 180$ diagram and compared to meteoric water line of Craig (1961) to identify fluid origin and process, i.e. meteoric, magmatic, mixing, boiling, vaporization and precipitation (Craig,1961; Truesdell,1977, Ellis \& Mahon,1977).

Table 2. Chemical and isotopic constituents (unit: o/oo) of Gedongsongo manifestation,

\begin{tabular}{|c|c|c|}
\hline \multicolumn{3}{|c|}{ Ungaran geothermal prospect, Central J } \\
\hline Location & West Ung-01 & East Ung-02 \\
\hline $\mathrm{pH}$ & 2 & 6.7 \\
$\mathrm{Li}$ & 0.1 & - \\
$\mathrm{Na}$ & 91.8 & 17.6 \\
$\mathrm{~K}$ & 54.3 & 6.2 \\
$\mathrm{Ca}$ & 1.1 & 10.9 \\
$\mathrm{Mg}$ & 40.4 & 3.7 \\
$\mathrm{Cl}$ & 753.3 & 790.9 \\
$\mathrm{SO}_{4}$ & 3008.3 & 5.7 \\
$\mathrm{HCO}_{3}$ & - & - \\
$\mathrm{SiO}_{2}$ & 411.0 & 189.6 \\
\hline$\delta^{18} \mathrm{O}$ & 2.68 & -8.19 \\
$\delta \mathrm{D}$ & -9.2 & -49.4 \\
\hline
\end{tabular}

local meteoric water (code: cold creek) has : $\delta 18 \mathrm{O}=-7.7, \delta \mathrm{D}=-46.6$ in o/oo. 
The West Ung-01 is more sulphate rich water with a significant amount of chloride as illustrated. This composition suggests a mixing process has been occurring in region.

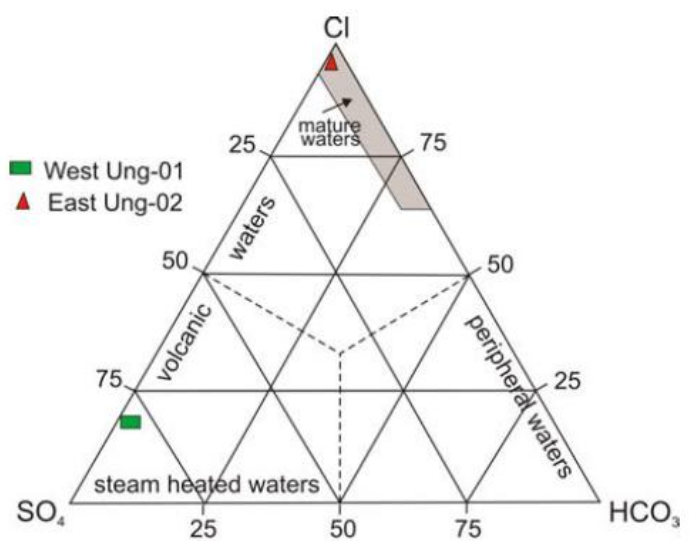

Fig. 5. Gedongsongo water type based on SO4-Cl-HCO3 ternary diagram of Giggenbach 1991.

The isotope data is parallel with this interpretation as the West Ung-01 shows enrichment of $\delta 180$ relative to Craig meteoric water line, but does not reaches the magmatic box area where $\delta 180$ is higher (enrichment in 180 content than those 160 as commonly occur at igneous rock and in water reaction contact with magma; Ellis \& Mahon, 1977). Although East Ung-02 is classified as mature water type but has depleted $\delta 180$ and lies on the global meteoric water line of Craig (1961).

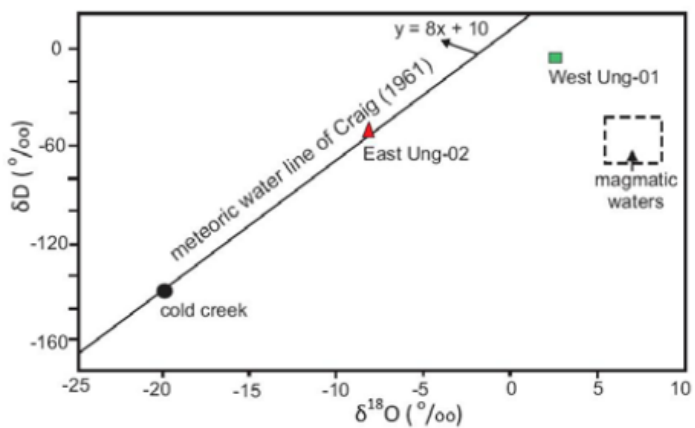

Fig. 6. Gedongsongo water type based on SO4- Cl-HCO3 ternary diagram of Giggenbach 1991.

\subsection{Alternative Geothermal Energy Uses}

Besides power resources, geothermal energy can be harnessed for other means as well. Thanks to geothermal water, there are natural hot springs all over the world and many people enjoy the warm waters and its restorative effects. Geothermal water can also be beneficial for growing agricultural products in a greenhouse within a cold or icy climate.

Geothermal waters can be harnessed to create space heating in buildings or even to keep streets and sidewalks warm enough to prevent icing over. Several cities have actually used geothermal energy in this unique manner.

\section{Result and discussion}

Gedongsono fluid type is classified as acid sulfatechloride water which consistent with collapsed structure processes. A slight magmatic fluid influence is recognized in the western part of Gedongsongo, where the active manifesatotions exist; this suggest that a mixing process is occurring in this region. To test this interpretation, we plan additional samples will be collected and analyzed (in particular for isotope) in the near future. 


\section{Conclusion}

Geothermal power plant really needed to decrease dependence in fossil fuels. Gedongsongo manifestations have a good geothermal prospect. Beside that, geothermal power plant is renewable energy and also be beneficial for growing agricultural products. There are high expectations that geothermal energy as the biggest support energy in Indonesia.

\section{Acknowledgements}

The authors are really thankful to Mr Dicky Muslim who help us to finish this paper.

\section{References}

[1] Van Bemmelen, R.W. (1949), The geology of Indonesia, vol.IA, Martinuj Nujhoff, The Hague.

[2] Hague. Browne, P.R.L. (1999), Hydrothermal Alteration, Lecture note 655.611, Geothermal Institute, Auckland University.

[3] Craig, H. (1961), "Isotopic variations in meteoric waters", Science, 133, 1702-1703.

[4] Ellis, A.J., Mahon, W.A.J. 1977, Chemistry and geothermal systems, Academic Press, New York.

[5] van Bemmelen, R.W. (1949), The geology of Giggenbach, W.F. (1991), Chemical techniques in geothermal exploration: in Applications of Geochemistry in Geothermal Reservoir Development (ed,F.D’Amore),119-144.

[6] Hamilton, W. (1979), Tectonics of the Indonesia region, Gelogical Survey Professional Paper 1078, US Govt Printing Office, Washington.

[7]Nukman ,Mochamad. 2009. Overview of Gedongsongo Manifestations of the Ungaran Geothermal Prospect, Central Java, Indonesia : a preliminary account.

[8]. IGA-International geothermal association, http://www.geothermal-energy.org

[9]. Green Chip Stocks, http://www.greenchipstocks.com/articles/renewable-energy-capacities-bycountry/765

[10] Anantha, A. and Chowhan P.L., Strategies for a nation-wide survey of renewable energy resources available in each village in India, Rural Energy Management", Deep \& Deep Publication, New Delhi., p.p.-2181-2186.

[11] Kakkar, Vinay, Nirmal Kr Agarwal, Narendra Kumar. 2012. Geothermal Energy: New Prospect, International Journal of Advancess in Engineering \& Technology

[12]. Cosimo Stallo, Mauro De Sanctis, Marina Ruggieri, Igor Bisio, Mario Marchese, "ICT Applications in Green and Renewable Energy Sector, Workshops on Enabling Technologies: Infrastructure for Collaborative Enterprises-2010, p.p., 175-179.

[13]. M. O'Sullivana, A. Yeha and W. Manningtonb, "Renewability of geothermal resources," Geothermics, vol. 39, pp. 314-320, 2010.

[14]. L. Rybach, "Geothermal energy: sustainabilityand the environment," Geothermics, vol. 32, pp. 463-470, 2003. 